May '68 


\section{Protest and Social Movements}

Recent years have seen an explosion of protest movements around the world, and academic theories are racing to catch up with them. This series aims to further our understanding of the origins, dealings, decisions, and outcomes of social movements by fostering dialogue among many traditions of thought, across European nations and across continents. All theoretical perspectives are welcome. Books in the series typically combine theory with empirical research, dealing with various types of mobilization, from neighborhood groups to revolutions. We especially welcome work that synthesizes or compares different approaches to social movements, such as cultural and structural traditions, micro- and macro-social, economic and ideal, or qualitative and quantitative. Books in the series will be published in English. One goal is to encourage nonnative speakers to introduce their work to Anglophone audiences. Another is to maximize accessibility: all books will be available in open access within a year after printed publication.

\section{Series Editors}

Jan Willem Duyvendak is professor of Sociology at the University of Amsterdam. James M. Jasper teaches at the Graduate Center of the City University of New York. 


\title{
May '68
}

Shaping Political Generations

\author{
Julie Pagis
}


Originally published as Mai 68, un pavé dans leur histoire (2014)

(C) Presses de la Fondation des Sciences Politiques

Translated by Katharine Throssell
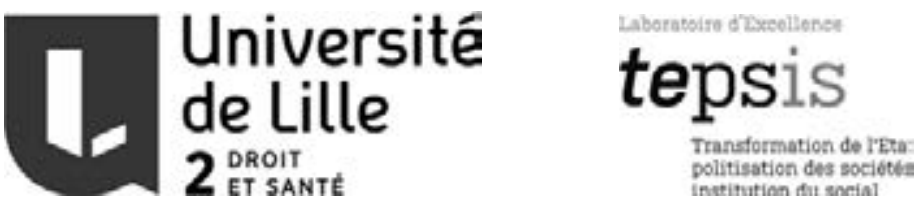

This translation was made possible thanks to financial support from CERAPS (Centre d'études et de recherches administratives, politiques et sociales) from the University of Lille 2, and from the LabeX TEPSIS at the EHESS (ANR-11-LABX-oo67).

Cover photo: (C) Claude Bourquelot

Cover design: Coördesign, Leiden

Typesetting: Crius Group, Hulshout

$\begin{array}{ll}\text { ISBN } & 9789462983755 \\ \text { e-ISBN } & 9789048534128 \text { (pdf) } \\ \text { DOI } & 10.5117 / 9789462983755 \\ \text { NUR } & 740\end{array}$

(C) Julie Pagis / Amsterdam University Press, Amsterdam 2018

All rights reserved. Without limiting the rights under copyright reserved above, no part of this book may be reproduced, stored in or introduced into a retrieval system, or transmitted, in any form or by any means (electronic, mechanical, photocopying, recording or otherwise) without the written permission of both the copyright owner and the author of the book.

Every effort has been made to obtain permission to use all copyrighted illustrations reproduced in this book. Nonetheless, whosoever believes to have rights to this material is advised to contact the publisher. 
To Agnes and Jean-Jacques,

my parents 
